\title{
Malignancy after Pediatric Kidney Transplantation: The 30-Year Experience of a Single Center
}

\author{
Jiwon Jung, M.D. ${ }^{1}$ \\ Young Seo Park, M.D., Ph.D. ${ }^{1}$ \\ Duck Jong Han, M.D., Ph.D. ${ }^{2}$ \\ Department of Pediatrics', Asan \\ Medical Center Children's Hospital, \\ University of Ulsan College of \\ Medicine, Seoul, Korea, Department \\ of Surgery ${ }^{2}$, Asan Medical Center, \\ University of Ulsan College of \\ Medicine, Seoul, Korea \\ Corresponding author: \\ Young Seo Park, M.D., Ph.D. \\ Department of Pediatrics, Asan Medical \\ Center Children's Hospital, University of \\ Ulsan College of Medicine, 88, Olympic-ro \\ 43-gil, Songpa-gu, Seoul, 05505, Korea \\ Tel: $+82-2-3010-3376$ \\ Fax: +82-2-473-3725 \\ E-mail:yspark@amc.seoul.kr
}

Received: 27 May 2020

Revised: 27 July 2020

Accepted: 30 August 2020
Objectives: We aimed to investigate the incidence, manifestations, and outcomes of malignancy after pediatric kidney transplantation (KT) at our center over 30 years. Methods: We retrospectively reviewed the medical records of 155 patients under 18 years of age who underwent KT between January 1990 and February 2020 at Asan Medical Center.

Results: Twelve patients (7.7\%) were diagnosed with a malignancy after KT. Malignancy was diagnosed after a mean period of $6.4 \pm 5.9$ years (median 4.6, range $0.5-20.6$ years) after KT. Nine (75.0\%) of the 12 cancer patients were diagnosed with post-transplant lymphoproliferative disease (PTLD), and the other three had papillary thyroid cancer, mucoepidermoid cancer of the hard palate, and T-cell acute lymphoblastic leukemia, respectively. PTLD was diagnosed within a mean of 3.7 \pm 3.4 years (median 3.7, range 0.5-9.8 years) after KT. Five patients diagnosed with PTLD were cured without recurrence. Three patients with PTLD died from the disease, and one patient with mucoepidermoid cancer from a non-PTLD malignancy died after progression, despite surgical resection and chemotherapy. Three (33.3\%) of the nine survivors progressed to end-stage renal disease (ESRD) after completing cancer treatment. No patient with post-transplant malignancy (PTM) experienced critical renal deterioration during cancer treatment.

Conclusion: PTLD was the most common PTM, occurring at $5.8 \%$ of the pediatric KT patients after KT in our center. Careful follow up is needed particularly considering the risk of PTLD after $\mathrm{KT}$ in children.

Key words: Pediatric, Kidney transplantation, Post-transplant malignancy, Posttransplant lymphoproliferative disease

\section{Introduction}

Pediatric kidney transplantation (KT) is the treatment of choice for children with end-stage renal disease (ESRD). Annual cases of pediatric KT have steadily increased up to 70 cases per year in South Korea ${ }^{1)}$. The renewed kidney allocation system, which has been valid since 2018, prioritizes children younger than 19 years on the transplant waitlist for pediatric cadaveric donations. With the longer life expectancy and graft survival granted by advances in immunosuppressant therapy, long-term complications associated with significant morbidity and mortality, such as malignancies, are becoming more of a concern for pediatric transplantation recipients ${ }^{2)}$. Malignancies occurring after KT result from various complex factors, including the immu-
This is an open-access article distributed under the terms of the Creative Commons Attribution Non-Commercial License (http:// creativecommons.org/licenses/by-nc/4.0/) medium, provided the original work is properly cited.

Pediatric Nephrology 
nological condition of the recipient, immunosuppressive treatment, oncogenic viruses, and other possible synergistic effects ${ }^{3)}$. The epidemiological pattern of malignancies among pediatric KT recipients is known to differ from that among adult $\mathrm{KT}$ recipients and the general population. While malignant lymphoma and non-melanoma skin cancer, thyroid cancer, stomach cancer have been identified as common post-transplant malignancies (PTMs) among adults, including at our center ${ }^{4,5)}$, post-transplantation lymphoproliferative disease (PTLD) and squamous cell carcinomas or basal cell carcinomas of the skin are commonly reported PTMs among pediatric patients after long-term follow-up ${ }^{3,6}$. PTLD is known to be associated with EpsteinBarr virus (EBV) infection, either primary infection or reactivation due to immunosuppression ${ }^{7}$. Risk factors for PTLD include EBV-naïve recipients with EBV-positive donors, younger age at transplantation, more aggressive immunosuppression; additionally, PTLDs are most likely to arise within the first year after transplantation ${ }^{8,9)}$. To evaluate incidence, malignancy types, manifestations, and outcomes, we analyzed our single-center experience of long-term follow-up of pediatric KT recipients.

\section{Materials and methods}

\section{Study design and participants}

From January 1990 through February 2020, 155 patients younger than 18 years underwent solitary KT at Asan Medical Center Children's Hospital. Nearly three-quarters $(\mathrm{n}=110,71 \%)$ of the patients received living-donor allografts, and the rest of patients underwent cadaveric donor KT. We retrospectively reviewed the medical records of these 155 patients and captured data pertaining to demographic characteristics, the occurrence of malignancies and their clinical course, means of immunosuppression, and renal outcomes. Renal function, reflected by the glomerular filtration rate (GFR), was estimated using the modified Schwartz formula ${ }^{10)}$ for patients with PTMs, before the cancer diagnosis and during treatment for the malignancy, and at the most recent follow-up.

\section{Immunosuppressant protocols}

Each pediatric KT recipient received maintenance im- munosuppression with or without an induction regimen, adopted from the KT regimen for adults at our center ${ }^{11}$. During the first decade of the study period (1990s), the immunosuppressive regimen consisted of a calcineurin inhibitor (CNI), azathioprine (AZT), and a corticosteroid without an induction regimen. Since the 2000s, the immunosuppressive regimen changed to include a CNI (tacrolimus or cyclosporine), mycophenolic acid, and a corticosteroid. For patients with immunological risk factors, such as highly sensitized individuals or those with previous graft loss due to rejection, and those who wish to avoid the long-term use of steroids, an induction regimen of rabbit antithymocyte globulin (Thymoglobulin; Genzyme, Cambridge, MA, USA) was administered. However, in 2007, monoclonal interleukin-2 receptor antibody (basiliximab) replaced thymoglobulin as the induction agent and settled into the basic regimen for solid organ transplantation, including KT, at our center. In summary, for the latter half period of the study period, patients were initiated on tacrolimus $(0.05-0.1 \mathrm{mg} / \mathrm{kg} /$ day, target level $7-10 \mathrm{ng} / \mathrm{mL}$, reduced to 6-8 ng/mL 1-2 weeks after KT), mycophenolate mofetil (MMF) (300-450 mg/m² two times per day), and methylprednisolone $(15 \mathrm{mg} / \mathrm{kg} / \mathrm{day}$ [or $500 \mathrm{mg} /$ day for patients weighing more than $35 \mathrm{~kg}$ ] intraoperatively, $7.5 \mathrm{mg} /$ $\mathrm{kg} /$ day [or $250 \mathrm{mg} /$ day for patients weighing more than 35 $\mathrm{kg}$ ] on post-KT day 2 , and $3 \mathrm{mg} / \mathrm{kg} /$ day [or $125 \mathrm{mg}$ for patients weighing more than $35 \mathrm{~kg}$ ] on post-KT day 3 , and then gradually reduced thereafter). Basiliximab was administered on the day of KT and post-KT day 4 (two doses of $20 \mathrm{mg}$ each for patients weighing more than $35 \mathrm{~kg}$, or two doses of $10 \mathrm{mg}$ each for patients weighing less than $35 \mathrm{~kg}$ ). We kept tacrolimus trough levels between 6 and $8 \mathrm{ng} / \mathrm{mL}$ for the first year, and between 3 and $5 \mathrm{ng} / \mathrm{L}$ thereafter. Cyclosporine trough levels were kept between 150 and 175 $\mathrm{ng} / \mathrm{mL}$ for the first 3 months, between 100 and $150 \mathrm{ng} / \mathrm{mL}$ for the next 9 months, between 75 and $100 \mathrm{ng} / \mathrm{mL}$ for the next year, and between 50 and $75 \mathrm{ng} / \mathrm{mL}$ thereafter ${ }^{7}$.

\section{Statistical analysis}

Categorical variables are presented as tallies and percentages. Continuous variables are presented as means \pm standard deviations, and medians with ranges. The KaplanMeier method was used to analyze the cumulative incidence free from malignancy. All statistical analyses were perfor- 
med using SPSS Statistics for Windows, version 21.0 (IBM Corp., Armonk, NY, USA).

\section{Results}

A total of 155 patients were included in this study who received KT during the study period (Male:Female=95:60). The KT recipients had a mean age of $13.2 \pm 4.2$ years (median 14.3 , range $1.4-18.0$ years). The mean follow-up period was $11.5 \pm 8.3$ years (median 9.6, range $0.1-28.1$ years). In total, 12 recipients $(7.7 \%)$ were diagnosed with a malignancy after KT (Male:Female=6:6). The mean age at cancer diagnosis was 19.4 \pm 7.4 years. These patients underwent $\mathrm{KT}$ at a mean age of $13.0 \pm 4.0$ (median 12.7, range 4.4-18.0) years. The mean interval between $\mathrm{KT}$ and malignancy diagnosis was $6.4 \pm 5.9$ (median 4.6, range 0.5-20.6) years. The overall cumulative incidence of malignancy was $13.8 \%$, with a cumulative incidence of $7.7 \%$ at 10 years post-KT, $10.2 \%$ at 15-20 years post-KT (Fig. 1). Of the 12 patients diagnosed with PTMs, three (25\%; all with PTLD) were diagnosed with their PTMs within the first year post-KT.

Four types of cancer were diagnosed among the 12 PTM patients: nine patients with PTLD (75.0\%, Male:Female= 4:5), one patient with T-cell acute lymphocytic leukemia (ALL) (8.3\%), one patient with mucoepidermoid cancer of the hard palate, and the one patient with papillary thyroid cancer. With an overall incidence of 5.8\% (9/155), PTLD was diagnosed within a mean of $3.7 \pm 3.4$ years (median 3.7, range 0.5-9.8 years) after KT, which was a shorter mean interval than other malignancies (mean 14.2, median 11.2, range 10.3-20.6 years). Characteristics of the patients with PTM are summarized in Table 1, and the clinical course of each patient is described in Table 2.

Seven (58.3\%) of 12 PTM patients received kidneys from cadaveric donors. The incidence of PTM among all cadaveric KT recipients was $15.6 \%$ (7/45). Five PTM patients (41.7\%) underwent living donor KT. The incidence of PTM among living donor KT recipients was 4.5\% (5/110) (Table 1). The immunosuppressant regimens at the time of diagnosis are described in Table 1 and Table 2.

Recipient and donor EBV serology data at the time of KT are described in Table 1. For the nine patients diagnosed with PTLD, primary EBV infection occurred at the time of
PTLD diagnosis in three patients. Four patients who had prior EBV exposure underwent conversion of serum EBV DNA titer from negative to positive at the time of diagnosis, and the remaining two patients with prior EBV exposure had a negative serum EBV DNA titer at the time of diagnosis. Three patients with primary EBV infection after KT were diagnosed with PTLD within 9 months after KT, showing an earlier onset than the other patients with PTLD (Table 2).

The first intervention for all PTM patients after their PTM diagnosis of was to moderate their immunosuppression (discontinue antimetabolite agents [AZT or MMF] and/or lower the CNI dosage) or convert their maintenance im-

\begin{tabular}{|c|c|}
\hline Characteristic & Value \\
\hline Sex (Male : Female) & $6: 6$ \\
\hline Age at transplantation (years) & $\begin{array}{l}13.0 \pm 4.0 \text { (median } \\
12.7,4.4-18.0)\end{array}$ \\
\hline Age at malignancy (years) & $\begin{array}{l}\text { 19.4 } \pm 7.4 \text { (median } \\
19.4,5.0-34.9)\end{array}$ \\
\hline $\begin{array}{l}\text { Interval between transplantation to malignancy } \\
\text { (years) }\end{array}$ & $\begin{array}{l}6.4 \pm 5.9 \text { (median } \\
4.6,0.5-20.6)\end{array}$ \\
\hline Donor type (Living related : Unrelated : Deceased) & $3: 2: 7$ \\
\hline \multicolumn{2}{|l|}{ Immunosuppression before diagnosis of PTM } \\
\hline Induction with IL-2 receptor blocker (basiliximab) & $8(66.7 \%)$ \\
\hline \multicolumn{2}{|l|}{ Maintenance regimen } \\
\hline AZA/FK/steroid & $4(33.3 \%)$ \\
\hline AZA/CyA/steroid & $2(16.7 \%)$ \\
\hline MMF/FK/steroid & $5(41.7 \%)^{*}$ \\
\hline FK & $1(8.3 \%)$ \\
\hline \multicolumn{2}{|l|}{ Malignancy type } \\
\hline Hematologic & $10(83.3 \%)$ \\
\hline PTLD & 9 \\
\hline T-cell ALL & 1 \\
\hline Non-hematologic & $2(16.7 \%)$ \\
\hline Thyroid cancer & 1 \\
\hline Mucoepidermoid cancer & 1 \\
\hline $\begin{array}{l}\text { EBV serostatus at KT for PTLD patients (recipient/ } \\
\text { donor) }\end{array}$ & 9 \\
\hline EBVVCA IgG $-/+$ & $3(33.3 \%)$ \\
\hline EBVVCA lgG $+/+$ & $2(22.2 \%)$ \\
\hline EBVVCA IgG NA/NA & $1(11.1 \%)$ \\
\hline EBVVCA lgG $+/ N A$ & $3(44.4 \%)$ \\
\hline
\end{tabular}

*One female pt had acute cellular rejection 11 months before diagnosis of PTLD, necessitating higher level of immunosuppression before diagnosis of PTLD.

Abbreviations: PTM, post-transplant malignancy; AZA, azathioprine; FK, tacrolimus; CyA, cyclosporine; MMF, mycophenolate mofetil; PTLD, posttransplant lymphoproliferative disorder; ALL, acute lymphoblastic lymphoma; EBV, Epstein-Barr virus; VCA, viral capsid antigen; NA, not applicable. 
Table 2. Clinical Course of Patients with PTM

\begin{tabular}{|c|c|c|c|c|c|c|c|c|c|c|c|c|c|c|c|c|}
\hline $\mathrm{Pt}$ & Sex & $\begin{array}{l}\text { Underlying } \\
\text { disease }\end{array}$ & $\begin{array}{l}\text { RRT } \\
\text { prior } \\
\text { to KT }\end{array}$ & $\begin{array}{l}\text { Age } \\
\text { at KT } \\
\text { (years) }\end{array}$ & $\begin{array}{l}\text { Donor } \\
\text { type }\end{array}$ & Symptoms & $\begin{array}{l}\text { Location } \\
\text { of PTM }\end{array}$ & Dx & $\begin{array}{l}\text { IS at the } \\
\text { time of } \\
\text { Dx }\end{array}$ & $\begin{array}{l}\text { EBV load } \\
\text { at the } \\
\text { time of Dx }\end{array}$ & $\begin{array}{l}\text { Interval } \\
\text { between } \\
\text { KT-PTM }\end{array}$ & Tx & Px & $\begin{array}{c}\text { History of } \\
\text { rejection } \\
\text { before } \\
\text { PTM }\end{array}$ & $\begin{array}{c}\text { Renal } \\
\text { deterioration } \\
\text { during Tx }\end{array}$ & $\begin{array}{c}\text { Renal } \\
\text { function } \\
\text { at last } \\
\text { Follow-up }\end{array}$ \\
\hline 1 & $\mathrm{~F}$ & $\begin{array}{l}\text { Dysplastic } \\
\text { kidney }\end{array}$ & $\begin{array}{l}\mathrm{PD} / \\
\mathrm{HD}\end{array}$ & 4.4 & CDKT & $\begin{array}{l}\text { Anemia, } \\
\text { malaise }\end{array}$ & $\begin{array}{l}\text { Liver, kidney, } \\
\text { Bone marrow, } \\
\text { Multiple LNs }\end{array}$ & $\begin{array}{l}\text { PTLD- } \\
\text { DLBCL }\end{array}$ & $\begin{array}{l}\text { MMF, FK, } \\
\text { Steroid }\end{array}$ & $\begin{array}{c}10^{3}-10^{4} / \\
\mathrm{mL}\end{array}$ & 0.50 & $\begin{array}{c}\text { CTx } \\
\text { (Rituximab) }\end{array}$ & On CTx & $\begin{array}{c}\text { CAN at } \\
1 y r\end{array}$ & None & Normal \\
\hline 2 & M & $\begin{array}{c}\text { Bilateral } \\
\text { dysplastic } \\
\text { kidney, VUR }\end{array}$ & PD & 10.58 & CDKT & LOC & Brain, lung & $\begin{array}{l}\text { PTLD- } \\
\text { DLBCL }\end{array}$ & $\begin{array}{l}\text { MMF, FK, } \\
\text { Steroid }\end{array}$ & $\begin{array}{c}10^{2}-10^{3} / \\
\mathrm{mL}\end{array}$ & 2.25 & $\begin{array}{c}\text { CTx } \\
\text { (Rituximab) }\end{array}$ & $C R$ & None & None & Normal \\
\hline 3 & M & $\begin{array}{l}\text { Congenital } \\
\text { GN, ectopic } \\
\text { kidney }\end{array}$ & PD & 11.08 & CDKT & $\begin{array}{l}\text { Abdominal } \\
\text { pain }\end{array}$ & Small bowel & $\begin{array}{l}\text { PTLD- } \\
\text { DLBCL }\end{array}$ & $\begin{array}{l}\text { AZT, FK, } \\
\text { Steroid }\end{array}$ & $\begin{array}{c}10^{3}-10^{4} / \\
\mathrm{mL}\end{array}$ & 8.25 & $\begin{array}{c}\text { CTx } \\
\text { (Rituximab) }\end{array}$ & $C R$ & None & None & $\begin{array}{c}\text { CKD Stage } \\
3\end{array}$ \\
\hline 4 & $\mathrm{~F}$ & Unknown & $\begin{array}{l}\mathrm{HD} / \\
\mathrm{PD}\end{array}$ & 15.42 & LDKT & Arm pain & $\begin{array}{l}\text { Rt. Proximal } \\
\text { humerus, Liver, } \\
\text { Lung }\end{array}$ & $\begin{array}{l}\text { PTLD- } \\
\text { DLBCL }\end{array}$ & $\begin{array}{l}\text { MMF, FK, } \\
\text { Steroid }\end{array}$ & $\begin{array}{c}10^{4}-10^{5} / \\
\mathrm{mL}\end{array}$ & 4.08 & $\begin{array}{c}\text { CTx } \\
\text { (Rituximab) }\end{array}$ & $C R$ & $\begin{array}{l}\text { ATCMR at } \\
3 \text { years }\end{array}$ & None & $\begin{array}{c}\text { CKD stage } \\
4\end{array}$ \\
\hline 5 & M & Unknown & PD & 17.42 & LDKT & $\begin{array}{l}\text { Lt neck } \\
\text { mass }\end{array}$ & $\begin{array}{l}\text { Lt. neck, bone, } \\
\text { multiple LNs }\end{array}$ & $\begin{array}{l}\text { PTLD- } \\
\text { DLBCL }\end{array}$ & $\begin{array}{l}\text { MMF, FK, } \\
\text { Steroid }\end{array}$ & $\begin{array}{c}10^{4}-10^{5} / \\
\mathrm{mL}\end{array}$ & 0.50 & $C T x$ & $C R$ & None & None & $\begin{array}{c}\text { ESRD On } \\
\text { HD }\end{array}$ \\
\hline 6 & $\mathrm{~F}$ & Unknown & PD & 18.5 & CDKT & $\begin{array}{l}\text { Lumbar } \\
\text { pain }\end{array}$ & Sacral spine, ala & $\begin{array}{l}\text { PTLD- } \\
\text { DLBCL }\end{array}$ & $\begin{array}{l}\text { MMF, FK, } \\
\text { Steroid }\end{array}$ & $\begin{array}{c}10^{3}-10^{4} / \\
\mathrm{mL}\end{array}$ & 0.75 & $\begin{array}{c}\text { CTx } \\
\text { (Rituximab) }\end{array}$ & $C R$ & None & None & Normal \\
\hline 7 & $\mathrm{~F}$ & RPGN & PD & 10.83 & CDKT & $\begin{array}{l}\text { Abdominal } \\
\text { pain }\end{array}$ & $\begin{array}{l}\text { Liver, spleen, } \\
\text { Retroperitoneal } \\
\text { LNs }\end{array}$ & $\begin{array}{l}\text { PTLD- } \\
\text { DLBCL }\end{array}$ & $\begin{array}{l}\text { AZT, CsA, } \\
\text { Steroid }\end{array}$ & - & 3.67 & $C T x$ & Expire & None & & \\
\hline 8 & M & $\begin{array}{l}\text { Alport } \\
\text { syndrome }\end{array}$ & PD & 10.92 & LDKT & Anemia & Small bowel & $\begin{array}{l}\text { PTLD- } \\
\text { DLBCL }\end{array}$ & $\begin{array}{l}\text { AZT, FK, } \\
\text { Steroid }\end{array}$ & Negative & 9.83 & Surgery, CTx & Expire & None & $\begin{array}{l}\text { None from } \\
\text { CKD stage } 4\end{array}$ & - \\
\hline 9 & $\mathrm{~F}$ & $\begin{array}{c}\text { Angio- } \\
\text { myolipoma }\end{array}$ & PD & 14.42 & CDKT & $\begin{array}{l}\text { Abdominal } \\
\text { pain }\end{array}$ & $\begin{array}{l}\text { Mesenteric LN, } \\
\text { Small bowel }\end{array}$ & $\begin{array}{l}\text { PTLD- } \\
\text { DLBCL }\end{array}$ & $\begin{array}{l}\text { MMF, FK, } \\
\text { Steroid }\end{array}$ & $\begin{array}{c}10^{5}-10^{6} / \\
\mathrm{mL}\end{array}$ & 5.08 & $\begin{array}{c}\text { CTx } \\
\text { (Rituximab) }\end{array}$ & Expire & None & - & - \\
\hline 10 & M & $\begin{array}{c}\text { Reflux } \\
\text { nephropathy }\end{array}$ & - & 14.33 & LDKT & $\begin{array}{c}\text { No } \\
\text { Symptom }\end{array}$ & $\begin{array}{l}\text { Rt. lower lobe of } \\
\text { Thyroid }\end{array}$ & PTC & $\begin{array}{l}\text { MMF, } \\
\text { CsA, } \\
\text { Steroid }\end{array}$ & - & 20.58 & Surgery & $C R$ & None & None & $\begin{array}{c}\text { ESRD on } \\
\text { HD }\end{array}$ \\
\hline 11 & M & VUR & $H D$ & 10.67 & LDKT & $\begin{array}{l}\text { Abdominal } \\
\text { pain }\end{array}$ & Bone marrow & T-ALL & FK & $\begin{array}{c}10^{3}-10^{4} / \\
\mathrm{mL}\end{array}$ & 11.17 & $C T x$ & $C R$ & $\begin{array}{l}\text { CAN at } \\
\text { lyr }\end{array}$ & $\begin{array}{l}\text { None from } \\
\text { CKD stage } 4\end{array}$ & ESRD \\
\hline 12 & $\mathrm{~F}$ & MPGN & $\begin{array}{l}\mathrm{HD} / \\
\mathrm{PD}\end{array}$ & 17.42 & CDKT & $\begin{array}{l}\text { Palpable } \\
\text { mass }\end{array}$ & Rt. hard palate & $\begin{array}{l}\text { Muco- } \\
\text { epidermoid } \\
\text { cancer }\end{array}$ & $\begin{array}{l}\text { AZT, FK, } \\
\text { Steroid }\end{array}$ & Negative & 10.33 & $\begin{array}{c}\text { Surgery, CTX, } \\
\text { RTx }\end{array}$ & Expire & None & - & - \\
\hline
\end{tabular}

Abbreviations: PTM, post-transplantation malignancy; KT, kidney transplantation; Pt, patient; RRT, renal replacement therapy; Dx, diagnosis; IS, immunosuppressant; Tx, treatment; Px, prognosis; RPGN, rapidly progressive glomerulonephritis; MPGN, membranoproliferative glomerulonephritis; VUR, vesicoureteral reflux; GN, glomerulonephritis; PD, peritoneal dialysis; HD, hemodialysis; CDKT, cadaveric donor kidney transplantation; LDKT, living donor kidney transplantation; LOC, loss of consciousness; LN, lymph node; DLBCL, diffuse large B-cell lymphoma; PTC, papillary thyroid carcinoma; T-ALL, T-cell acute lymphoblastic leukemia; AZT, azathioprine; CsA, cyclosporine; MMF, mycophenolate mofetil; FK, tacrolimus; CCOR, deflazacalcort; CTx, chemotherapy; RTX, radiotherapy; ATCMR, acute T-cell mediated rejection; CAN, chronic allograft nephropathy; CKD, chronic kidney disease; ESRD, end-stage renal disease.

munosuppression medications of CNI to sirolimus. Seven patients (six patients with PTLD and one patient with thyroid cancer) were changed from tacrolimus to sirolimus. The patients diagnosed with PTLD and T-cell ALL all underwent chemotherapy according to the extent of disease and pathologic diagnosis. Patient 12 , with a mucoepidermoid tumor, underwent an excision operation followed by adjuvant chemotherapy, and Patient 10 with PTC underwent surgical resection of thyroid cancer with cervical lymph node dissection.

The overall mortality rate among the 12 PTM patients was $33.3 \%$ (4/12). Among the nine patients diagnosed with PTLD, three patients (33.3\%) died after disease progression (Patient 8) or infection during chemotherapy (Patient 7 and
Patient 9). Five patients were cured without recurrence, and one patient, at the time that this article was composed, was still on chemotherapy for residual lesions. Patient 12, with mucoepidermoid cancer of the hard palate, also died after disease progression despite surgical resection and chemotherapy. The patients with thyroid cancer and T-cell ALL were all cured without recurrence. All patients who survived did not show deterioration of renal function during PTM treatment. However, during follow-up, four (44.9\%) of nine PTM survivors had preserved renal function, and two patients had deteriorated renal function, with a median GFR of $34.5 \mathrm{ml} / \mathrm{min} / 1.73 \mathrm{~m}^{2}$ (range $30-39 \mathrm{ml} / \mathrm{min} / 1.73$ $\mathrm{m}^{2}$ ). The other three patients progressed to ESRD after a median of 33 months (range, 24-70 months) after PTM 


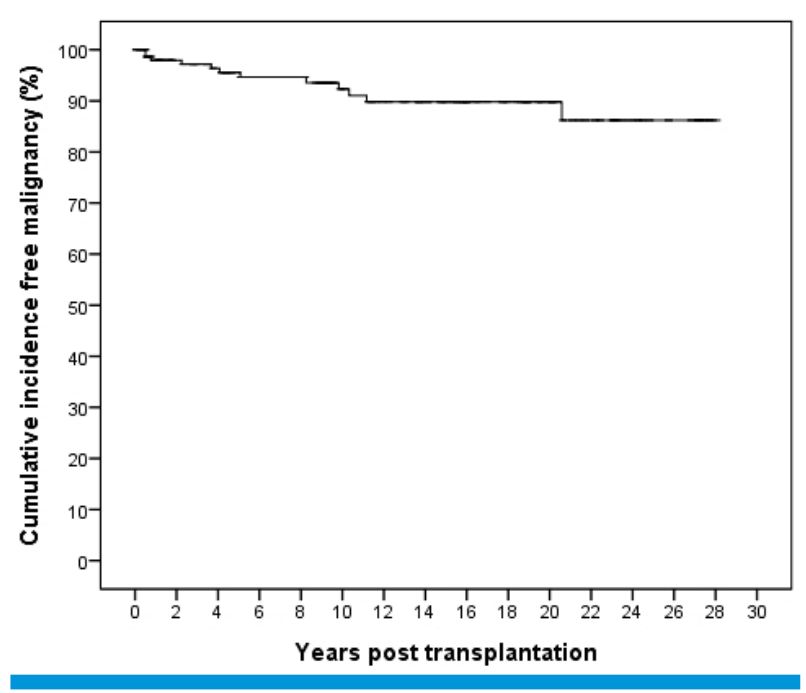

Fig. 1.Cumulative incidence free from malignancy for 155 pediatric kidney transplant recipients.

remission. At the time of composition of this article, two patients diagnosed with PTLD and thyroid cancer were on renal replacement therapy, and the patient with T-cell ALL had progressed to ESRD and were being considered for renal replacement therapy.

\section{Discussion}

PTMs have a significant impact on the morbidity and mortality of pediatric KT recipients. In this study, we evaluated the incidence of PTM over long-term follow-up and assessed the clinical course and factors associated with PTM development.

The overall incidence of PTM and overall incidence of PTLD in this cohort are comparable with previous studies, which have reported incidences ranging from 7.3-15.4\% for all types of PTM associated with pediatric KT; however, the PTLD incidence at our center was higher than the overall incidence estimates of 2.2-5.3\% reported elsewhere ${ }^{3,6,12}$. About half of the PTM cases occurred within 10 years after KT when analyzed according to the time to diagnosis (Fig. 1), and this trend was in line with a previous study by Koukourginanni et al., who reported findings from 20 years of follow-up in France, including a cumulative incidence of $6.9 \%$ at 10 years and $10.2 \%$ at 15 years ${ }^{3}$. However, Serrano et al. reported a higher incidence over a longer follow-up interval, showing cumulative PTM incidence values after pediatric KT in Minnesota of $4 \%$ at 10 years, $13 \%$ at 20 years, $26 \%$ at 30 years, and $36 \%$ at 40 years, which might be explained by the longer follow-up duration, which allowed them to detect and include the cases of adult-type epithelium-derived cancers ${ }^{6}$. These studies suggest that surveillance for PTMs associated with pediatric KT, such as PTLD, should be emphasized, especially during the first 10 years post-KT, and adult-type cancers should be included within the differential diagnosis thereafter.

We found sexual difference in terms of incidence of PTM in this study. While more male patients received KT (Male: Female=95:60), incidence of PTM was higher in female (10 $\%, 6 / 60)$ than in male $(6 \%, 6 / 95)$ which was accentuated in the incidence of PTLD (female $8 \%$, male $4 \%$ ). This higher incidence of PTM including PTLD in female was also noticed in the recent Korean study ${ }^{13)}$, although the sex was not evaluated as a factor for risk of PTLD or donor type was stratified according to recipient sex in the study. Compared with previous studies showing higher incidence of PTM in male ${ }^{3)}$, our results might be attributable to the higher rate of cadaveric donors in female PTM patients, or multifactorial effects including EBV serostatus, presence of acute rejection and possible sexual hormonal effects requiring elucidation .

The most frequently diagnosed PTM in our study was PTLD, which developed within a mean of $4.3 \pm 3.3$ years after KT at our center. PTMs other than PTLD were all diagnosed more than 10 years after KT. Patients with PTLD in our study underwent KT at younger age (mean 12.1 years, median 11 years) than the overall mean age of KT (13.2 years, median 14 years). The increased PTLD risk associated with a younger age at $\mathrm{KT}$ is mainly attributable to the frequent EBV seronegativity at the time of KT, and the predisposition to primary EBV and CMV infections in the early period after $\mathrm{KT}^{9,14)}$. One-third of the PTLD patients in our study were EBV-naïve before KT and had primary EBV infection at the time of PTLD diagnosis; all nine of the PTLD patients were diagnosed within 9 months after KT. It is obvious from these findings that young age and EBVnaïve status are necessary but not always sufficient for PTLD development. However, primary-EBV-associated PTLD had a more rapid onset within the first year after KT than other cases, emphasizing the importance of surveillance of early PTLD, especially for EBV-naïve KT recipients. This 
was also stressed by Schober et al. presenting the distinct characteristics of early and late PTLD after transplantation: early PTLD within 3 years of transplantation is mainly an EBV-driven, extra-nodal disease caused by insufficient immunosurveillance, unlike late-onset disease ${ }^{15)}$. Nevertheless, the fact that all histological diagnoses from our patients were consistent with diffuse-large B-cell lymphoma with extra-nodal involvement (liver, spleen, brain, small bowel, bone, lung), implies that EBV plays a role in the development of PTLD by infecting and inducing malignant transformation of B-cells ${ }^{4,13,16)}$.

Accumulating evidence suggests that it is not the choice of regimen but the intensity, especially the degree of T-cell immunosuppression, that is associated with the risk of $\mathrm{PTLD}^{9,17)}$. This is associated with the impairment of EBVspecific T-cell-mediated immunity, which disrupts cytotoxic T-cells to check the EBV-infected B-cells and promote the development of PTLD. The magnitude of immunosuppression of patients with PTLD could not be objectively confirmed and compared in this study, but the tacrolimus drug level (and the cyclosporine level in one patient) was almost within the target range according to the time after $\mathrm{KT}$, except for one patient who showed acute T-cell-mediated rejection with antibody-mediated rejection 11 months before the diagnosis of PTLD and was on a stronger immunosuppression regimen. Therefore, we could not fully verify the association between PTLD and the level of immunosuppression in this study. Other factors proposed to be associated with the development of PTLD, including complete HLA-DR mismatch, certain types recipient HLA, and host genetic variations, were not analyzed in this study and are yet to be further investigated in larger prospective studies $^{12,18-20)}$.

PTM treatment among our patients was adherent to the existing recommendations ${ }^{8}$. Patients all discontinued maintenance antimetabolite agents (AZT or MMF), and CNI doses were reduced. Additional chemotherapy was applied for all PTLD patients, including rituximab with CHOP (cyclophosphamide, doxorubicin, vincristine, prednisone) as the fundamental regimen ${ }^{9}$. Four of the six PTLD survivors, and all three patients with non-PTLD PTM changed from CNI to sirolimus while maintaining steroid therapy. Sirolimus, as a mammalian target of rapamycin (mTOR) inhibitor, has both immunosuppressive and antiprolifera- tive effects, and has been shown to inhibit tumor growth and progression". Pascual et al. reported the remission of 19 patients with post-KT PTLD with the addition of proliferation signal inhibitors and minimizing CNIs, with or without concurrent chemotherapy ${ }^{21)}$. Among seven patients who used sirolimus after the diagnosis of PTM at our center, six patients were cured without recurrence, but Patient 8 experienced recurrence with progression. Although adverse events such as poor wound healing, oral ulceration, and proteinuria have been reported with sirolimus, no severe adverse events were reported among our patients, supporting the utility of mTOR inhibitors for PTM including PTLD.

The PTM-associated mortality rate was highest in association with PTLD than other malignancies in our study, and higher compared with previously reported mortality rates. Not only uncontrolled PTLD without complete remission despite immunosuppression reduction with concurrent chemotherapy, but complications, such as neutropenia and infection during chemotherapy, also contributed to mortality in our study. This was unlike the finding, reported by Jeong et al., of a 100\% remission rate among PTLD patients for whom mortality was only associated with complications of infection, or the report, by McDonald et al., of $100 \%$ remission from a multicenter study with a mortality rate of $5.2 \%$ due to PTLD recurrence in one patient ${ }^{12,22)}$. The impact of PTM on allograft preservation is still debated. Serrano et al. reported an increased hazard ratio of both death and allograft loss among PTM patients compared with patients without PTM, while Francis et al. reported that PTM development was only associated with mortality, not allograft loss ${ }^{6,23)}$. Among our surviving PTM patients, allograft function was preserved during PTM treatment, even if the malignancy involved the allograft in one patient (Patient 1, Table 2.). Although one patient with PTLD, and two patients with other PTMs eventually progressed to $\operatorname{ESRD}(3.25,16.1$, and 21.1 years after KT respectively) due to rejection or chronic allograft nephropathy, no allograft loss occurred during PTM treatment in our study.

Although the significance of this study comes from the long-term follow up evaluation at a single center, there were some limitations to consider. First, the retrospective observational nature of the study and the small sample size limits the generalizability of the results. Regarding the EBV sero- 
logy, the timing of laboratory tests and the method of EBV load analysis might have changed over the course of the period under study, and this would have affected the detection of EBV, therefore preventing like-for-like comparisons for the entirety of the study period.

\section{Conclusion}

Among the pediatric PTMs detected in this cohort during the study period, PTLD was the most common malignancy, occurring in $5.6 \%$ of patients within a mean of $4.3 \pm$ 3.3 years after KT at our center. Careful surveillance is necessary, including monitoring for new-onset symptoms, physical examination, and regular follow-up for monitoring EBV serologic status, especially considering the risk of PTLD after KT in children. Although deterioration of allograft function was rare during PTM treatment, early diagnosis and intervention are crucial determinants of favorable survival outcomes.

\section{Conflicts of interest}

No potential conflict of interest relevant to this article was reported.

\section{Acknowledgment}

This study did not receive any external funding.

\section{Patient consent}

This study was approved by the institutional review board (IRB) of Asan Medical Center, and the consent was waived due to the nature of the retrospective study [IRB number 2020-0468].

\section{ORCID IDs}

Jiwon Jung https://orcid.org/0000-0001-5358-7966
Young Seo Park https://orcid.org/0000-0001-7653-2036

Duck Jong Han https://orcid.org/0000-0002-0990-6824

\section{References}

1. Annual national data repot from KONOS transplantation analysis [updated 2020.03.16. Available from: https://www.konos.go.kr/ konosis/common/bizlogic.jsp.

2. Samuel SM, Tonelli MA, Foster BJ, Alexander RT, Nettel-Aguirre A, Soo A, et al. Survival in pediatric dialysis and transplant patients. Clin J Am Soc Nephrol 2011;6:1094-9.

3. Koukourgianni F, Harambat J, Ranchin B, Euvrard S, Bouvier R, Liutkus $A$, et al. Malignancy incidence after renal transplantation in children: a 20-year single-centre experience. Nephrol Dial Transplant 2010;25:611-6.

4. Kim JH, Kim SS, Han DJ, Park SK. 49th European Renal Association-European dialysis and Transplant association Congress, Transplantation session: 502. 2012;94:847.

5. Heo J, Noh OK, Oh YT, Chun M, Kim L. Cancer risk after renal transplantation in South Korea: a nationwide population-based study. BMC Nephrol 2018;19:311.

6. Serrano OK, Bangdiwala AS, Vock DM, Chinnakotla S, Dunn TB, Finger EB, et al. Post-Transplant Malignancy after Pediatric Kidney Transplantation: Retrospective Analysis of Incidence and Risk Factors in 884 Patients Receiving Transplants Between 1963 and 2015 at the University of Minnesota. J Am Coll Surg 2017;225:18193.

7. You J, Kim M, Lee J, Han DJ, Park YS, Lee JH. Epstein-Barr virus infection in children with renal transplantation: A single-centre experience. Nephrology 2018;23:1039-45.

8. Dharnidharka VR, Araya CE. Post-transplant lymphoproliferative disease. Pediatr Nephrol 2009;24:731-6.

9. Al-Mansour Z, Nelson BP, Evens AM. Post-transplant lymphoproliferative disease (PTLD): risk factors, diagnosis, and current treatment strategies. Curr Hematol Malig Rep 2013;8:173-83.

10. Schwartz GJ, Munoz A, Schneider MF, Mak RH, Kaskel F, Warady $B A$, et al. New equations to estimate GFR in children with CKD. J Am Soc Nephrol 2009;20:629-37.

11. Kwon H, Kim YH, Choi JY, Sung S, Jung JH, Park S-K, et al. Analysis of 4000 kidney transplantations in a single center: Across immunological barriers. Medicine 2016;95:e4249.

12. Jeong HJ, Ahn YH, Park E, Choi Y, Yi NJ, Ko JS, et al. Posttransplantation lymphoproliferative disorder after pediatric solid organ transplantation: experiences of 20 years in a single center. Korean J Pediatr 2017;60:86-93.

13. Hyun H, Park E, Cho M, Min SI, Ha J, Kang HJ, et al. Post-Transplant Lymphoproliferative Diseases in Pediatric Kidney Allograft Recipients with Epstein-Barr Virus Viremia. J Korean Med Sci 2019; 34:e203.

14. Opelz G, Dohler B. Lymphomas after solid organ transplantation: 
a collaborative transplant study report. Am J Transplant 2004;4: 222-30.

15. Schober T, Framke T, Kreipe H, Schulz TF, Grohennig A, Hussein K, et al. Characteristics of Early and Late PTLD Development in Pediatric Solid Organ Transplant Recipients. Transplantation 2013;95.

16. Mynarek M, Hussein K, Kreipe HH, Maecker-Kolhoff B. Malignancies after pediatric kidney transplantation: more than PTLD?. Pediatr Nephrol 2014;29:1517-28.

17. Parker A, Bowles K, Bradley JA, Emery V, Featherstone C, Gupte G, et al. Diagnosis of post-transplant lymphoproliferative disorder in solid organ transplant recipients - BCSH and BTS Guidelines. Br J Haematol 2010;149:675-92.

18. Opelz G, Daniel V, Naujokat C, Dohler B. Epidemiology of pretransplant EBV and CMV serostatus in relation to posttransplant non-Hodgkin lymphoma. Transplantation 2009;88:962-7.

19. Opelz G, Dohler B. Pediatric kidney transplantation: analysis of donor age, HLA match, and posttransplant non-Hodgkin lymphoma: a collaborative transplant study report. Transplantation 2010;90:292-7.

20. Lustberg ME, Pelletier RP, Porcu P, Martin SI, Quinion CD, Geyer SM, et al. Human leukocyte antigen type and posttransplant lymphoproliferative disorder. Transplantation 2015;99:1220-5.

21. Pascual J. Post-transplant lymphoproliferative disorder--the potential of proliferation signal inhibitors. Nephrol Dial Transplant 2007;22 Suppl 1:i27-35.

22. McDonald RA, Smith JM, Ho M, Lindblad R, Ikle D, Grimm P, et al. Incidence of PTLD in Pediatric Renal Transplant Recipients Receiving Basiliximab, Calcineurin Inhibitor, Sirolimus and Steroids. Am J Transplant 2008;8:984-9.

23. Francis A, Johnson DW, Craig J, Teixeira-Pinto A, Wong G. Posttransplant lymphoproliferative disease may be an adverse risk factor for patient survival but not graft loss in kidney transplant recipients. Kidney Int 2018;94:809-17. 